\title{
A felső és alsó endoszkópiák indikációja, a diagnózisok megoszlása és minőségi mutatók 2010-2011-ben a Semmelweis Egyetem I. Belgyógyászati Klinikáján
}

\author{
Gönczi Lóránt dr. - Kürti Zsuzsanna dr. - Golovics Petra dr. \\ Végh Zsuzsanna dr. - Lovász Barbara dr. - Dorkó Andrea - Seres Anna \\ Sümegi Liza - Menyhárt Orsolya - Kiss Lajos dr. - Papp János dr. \\ Gecse Krisztina dr. - Lakatos Péter László dr.
}

Semmelweis Egyetem, Általános Orvostudományi Kar, I. Belgyógyászati Klinika, Budapest

\begin{abstract}
Bevezetés és célkitüzés: A Semmelweis Egyetem I. Belgyógyászati Klinikájának endoszkópos laboratóriumában vizsgálták a felső és alsó endoszkópiák indikációit, a diagnózisok megoszlását indikációk szerint, valamint a kolonoszkópiák minőségi mutatóit. Módszer: 2010. január 1. és 2011. december 31. között 2987 beteg felső és alsó endoszkópos vizsgálatának adatait elemezték (férfi/nő: 1361/1626, átlagéletkor: 60,7 év, SD: 16,7 év) a fekvő- és járóbeteg-megjelenések riportjaiból. Eredmények: A felső endoszkópiák során a jóindulatú fekélybetegség, nyelőcső-varicositas, gyomorpolip és gyomorrák előfordulási gyakorisága 10,8\%, 4,5\%, 6,1\% és 2,9\% volt. Az alsó endoszkópos vizsgálatok vastagbélpolipot, diverticulosist, daganatot és gyulladásos bélbetegséget 29,9\%,22,4\%,6,9\% és 9,7\%-ban írtak le. A betegek 26,3\%-át vizsgálták okkult/manifeszt GI-vérzés indikációjával. A vérzés indikációjával vizsgált betegek idősebbek voltak $(p<0,01)$, több volt a férfi $(p<0,001$, OR: 1,64$)$, gyakrabban szedtek acenocoumarol- vagy heparinkészítményeket $(\mathrm{p}<0,001)$, gyakoribb volt a jóindulatú fekélybetegség $(\mathrm{p}<0,001, \mathrm{OR}: 2,83)$ és nyelő́cső-varicositas $(\mathrm{p}<0,001$, OR: 2,79), a gasztroszkópiák, valamint a kolonoszkópiák során a colorectalis daganat $(\mathrm{p}<0,001, \mathrm{OR}$ : 3,27). A kolonoszkópiák 81\%-a volt komplett. Az inkomplett vizsgálat hátterében elégtelen előkészítés $(38,2 \%)$, technikai nehézség $(25,1 \%)$ és daganat miatti szúkület $(20,5 \%)$ állt. Következtetés: A diagnózisok megoszlása és a minőségi mutatók (adenomatalálat, komplettálási arány) megfeleltek az adott populációban várhatónak. Orv. Hetil., 2016, 157(52), 2074-2081.
\end{abstract}

Kulcsszavak: gasztroszkópia, kolonoszkópia, gastrointestinalis vérzés

\section{Indications, diagnoses and quality markers in upper and lower endoscopies in 2010 and 2011 at the 1st Department of Medicine, Semmelweis University, Budapest}

Introduction and aim: The aim was to assess the incidence of endoscopic findings based on the indication of the procedures in upper/lower endoscopies, and measuring quality indicators of colonoscopies at the lst Department of Medicine, Semmelweis University, Budapest. Method: Data of 2987 patients (male/female:1361/1626, mean age: 60.7 years(y), SD: 16.7y) between 01.01.2010 and 31.12.2011 were analyzed. Both inpatient and outpatient records were collected. Results: Incidence of peptic ulcer disease, esophageal varices, gastric polyps and gastric cancer were $10.8 \%, 4.5 \%, 6.1 \%, 2.9 \%$ in upper endoscopies, respectively. In colonoscopies colorectal polyps, diverticulosis, colorectal cancer and IBD were found in $29.9 \%, 22.4 \%, 6.9 \%, 9.7 \%$, respectively. In patients having upper endoscopy with GI bleeding indication, older age $(\mathrm{p}<0.001)$, male gender $(\mathrm{p}<0.001$, OR: 1.64$)$, acenocoumarol/heparin use $(\mathrm{p}<0,001$, peptic ulcers and esophageal varices were more frequent $(\mathrm{p}<0.001$, OR: 2.83 and $\mathrm{p}<0.001, \mathrm{OR}: 2.79)$, while in colonoscopies colorectal cancer had higher incidence $(\mathrm{p}<0.001, \mathrm{OR}: 3.27) .81 \%$ of colonoscopies were com- 
plete. Causes of incomplete procedures were ineffective bowel preparation (38.2\%), technical difficulties $(25.1 \%)$ and strictures (20.5\%). Conclusion: The endoscopic findings and quality indicators (adenoma detection rate, coecal intubation rate) were in line with that reported in published series.

Keywords: gastroscopy, colonoscopy, gastrointestinal hemorrhage

Gönczi, L., Kürti, Zs., Golovics, P., Végh, Zs., Lovász, B., Dorkó, A., Seres, A., Sümegi, L., Menyhárt, O., Kiss, L., Papp, J., Gecse, K., Lakatos, P. L. [Indications, diagnoses and quality markers in upper and lower endoscopies in 2010 and 2011 at the 1st Department of Medicine, Semmelweis University, Budapest]. Orv. Hetil., 2016, 157(52), 20742081.

(Beérkezett: 2016. augusztus 17.; elfogadva: 2016. október 31.)

\begin{abstract}
Rövidítések
$\mathrm{ADR}=$ adenomadetekciós ráta AGA $=$ American Gastroenter ological Association; ASA = aminoszalicilát $; \mathrm{ESGE}=$ European Society of Gastrointestinal Endoscopy; gFOBT = (guaiac fecal occult blood test) gvajakol okkult székletvér teszt; GI = gastrointestinalis; $\mathrm{iFOBT}=$ (immunochemical fecal occult blood test) immunkémiai okkult székletvér teszt; LMWH = (low molecular weight heparin) kis molekulatömegü heparin; NSAID = (non-steroidal anti-inflammatory drug) nem szteroid gyulladáscsökkentő gyógyszer; $\mathrm{SE}=$ Semmelweis Egyetem; TAGG = thrombocytaaggregáció-gátló
\end{abstract}

A gastrointestinalis (GI) traktusból származó vérzések adekvát kivizsgálása és kezelése, továbbá az endoszkópos vizsgálatok minőségi indikátorainak vizsgálata az endoszkópos centrumok nagy kihívása. Az endoszkópos technikák fejlődése az elmúlt évtizedekben jelentős előrelépést eredményezett a GI-traktus betegségeinek diagnosztikájában, lehetôséget biztosítva a nyálkahártyafelszín direkt vizsgálatára, amely szenzitivitásában és specificitásában felette áll a hagyományos radiológiai képalkotó módszereknek. A GI-traktusból származó vérzések az endoszkópos vizsgálat elvégzésének abszolút indikációját képzik [1].

A tápcsatornából származó vérzések irodalmi incidenciaadatai igen széles értékek között változnak (felső GIvérzés: 37-172/100 000 személyév, alsó GI-vérzés: 20,5-87/100 000 személyév), amely magyarázható populációs különbségekkel, illetve a különböző vizsgálatok eltérő esetdefinícióival. A legmagasabb incidenciaértékeket felső GI-vérzés esetén egy skót tanulmány, alsó GI-vérzésben pedig egy izlandi kohorsz adatai mutatják [2-5]. Az Egyesül Államokban 2005-ben készült vizsgálatok alapján a felső GI-vérzések incidenciája 8090/100 000 személyév, míg az alsó tápcsatorna vérzései 30-36/100 000 személyévre tehető $[6,7]$.

Lanas és mtsai 2009-ben publikált vizsgálatukban 10 spanyol kórházban vizsgálták az akut felső és alsó GIvérzések incidenciájában bekövetkezett változásokat 1996 és 2005 között. A felső GI-vérzések gyakorisága szignifikáns csökkenést (87/100 000 személyév vs. 47/100 000 személyév) mutatott a vizsgált időszakban, míg az alsó GI-vérzések incidenciájában trendszerű növekedés figyelhető meg (20/100 000 személyév vs. 33/100 000 személyév), vagyis a GI-vérzések két formájának gyakorisága közelít egymáshoz [8]. Hasonló eredményeket közölt két másik prospektív tanulmány is, azonban a felső GI-vérzések, illetve azon belül a peptikus fekélybetegségből származó vérzések incidenciájának csökkenése csak a fiatalabb, nem kórházban fekvő betegpopulációban volt megfigyelhető. Az idősebb betegpopulációban elmarad a gyakoriságok várt csökkenése, amelyre magyarázatul szolgálhat a magas átlagéletkor és a súlyos komorbiditások fennállása $[9,10]$.

Az akut felső GI-vérzések, különös tekintettel a gastroduodenalis fekélyekből származó vérzések gyakoriságát vizsgálva $R a ́ c z$ és mtsai kérdőíves adatgyüjtés során 62 gasztroenterológiai osztály adatait dolgozták fel. Eredményeikben a jelentett 6473 akut felső GI-vérzéses epizód 46,9\%-a származott gastroduodenalis fekélyből. A győri Petz Aladár Kórház beteganyagát retrospektíven vizsgálva a manifeszt felső GI-vérző és 24 órán belül urgens endoszkópián áteső betegeknél 28,4\%-ban volt fekélybetegség megállapítható $[11,12]$. Az alsó GI-vérzések gyakoriságáról Veszprém megyéből származnak adatok, ahol egy kétéves követési periódusban 77 betegnél észleltek akut alsó GI-vérzést, ez 22/100 000 személyév incidenciának felel meg [13].

Az elvégzett endoszkópos vizsgálatok becsült száma az Egyesült Államokban 2009-ben 2300 gasztroszkópia/100 000 fó, illetve 5100 kolonoszkópia/100 000 fó volt, amely az egészségügyre fordított anyagi források igen jelentős részét képezi [14]. Az endoszkópos vizsgálatok minőségének biztosítása, a minőséget jelző indikátorok meghatározása és vizsgálata minden ország számára elengedhetetlen. A kolonoszkópia a colorectalis rák és prekurzor laesióinak észlelésében magas szenzitivitása miatt az eljárások aranystandardja, azonban nem tekinthető tökéletes vizsgálóeljárásnak $[15,16]$. Egyes tanulmányok alapján a colorectalis rákkal diagnosztizált betegek 2-6\%-ában történt a megelőző három évben kolonoszkópia negatív eredménnyel, vagyis az esetek jelentős hányadában nem kerültek felismerésre a cancerosus vagy praecancerosus laesiók [17-19]. A kolonoszkópos vizsgálat minőségének megítélésére számos indikátor 
került leírásra az irodalomban, úgymint az adenomadetekciós ráta $(\mathrm{ADR})$, coecumintubációs ráta, endoszkópkihúzási idő, bélelőkészítés, szövődményráta [15, 20, 21]. Ezen minőségi indikátorok mérése, összehasonlítása a különböző gasztroenterológiai társaságok ajánlásaiban lefektetett célértékekkel alapvető az endoszkópos centrumok optimalizált müködése érdekében [15, 21].

Jelen tanulmányunkban a Semmelweis Egyetem (SE) I. Belgyógyászati Klinikáján 2010 és 2011-ben végzett endoszkópos vizsgálatok indikációit, a diagnózisok megoszlását és az elvégzett kolonoszkópiák minőségi indikátorait vizsgáltuk.

\section{Betegek és módszer}

A Semmelweis Egyetem I. Belgyógyászati Klinikáján 2010. január 1. és 2011. december 31. között összesen 2987 betegnél 1789 gasztroszkópiát és 1676 kolonoszkópiát végeztek (férfi/nő: 1361/1626, átlagéletkor a diagnózis idején: 60,71 év, SD: 16,69 év). A részletes klinikai adatokat az SE I. Belgyógyászati Klinika fekvőés járóbetegeinek adataiból gyưjtöttük össze retrospektív módon. A tanulmányt az SE TUKEB-engedélyével végeztük (TUKEB-szám: 34/2013).

Elemeztük az endoszkópos vizsgálatok indikációit (GI-vérzés vagy nem GI-vérzés az indikáció), a diagnózisok megoszlását indikáció, illetve életkor szerint, valamint számba vettük a társbetegségeket, a szedett gyógyszereket, a transzfúziós igényt, dohányzást és alkoholfogyasztást. Vizsgáltuk továbbá a komplett kolonoszkópiák arányát, illetve a nem komplett kolonoszkópiák hátterében álló okokat.

Vizsgálatunkban GI-vérzésként definiáltuk mind a manifeszt, mind pedig az okkult emésztőszervi vérzést. Az okkult GI-vérzés fennállását azon betegek esetén feltételeztük, akikben pozitív volt az okkultszékletvér-vizsgálatok eredménye (gFOBT vagy iFOBT teszt), vagy egyéb okkal nem magyarázható vashiányos anaemiával rendelkeztek.

Adataink feldolgozása során $\chi^{2}$-tesztet, Student Ttesztet és ANOVA-próbát használtunk. Statisztikai számításainkat az SPSS20 szoftver segítségével végeztük. A szignifikanciaszintet $\mathrm{p}<0,05$ értékben határoztuk meg.

\section{Eredmények}

\section{A leggyakoribb diagnózisok megoszlása felsö és alsó endoszkópiák során}

A felső endoszkópiák során a jóindulatú fekélybetegség, nyelőcső-varicositas, gyomorpolip és a gyomorrák elöfordulási gyakoriságai a következők voltak: 10,8\%, 4,5\%, 6,1\%, 2,9\%. A betegek 26,5\%-a került GI-vérzés indikációjával vizsgálatra, közöttük szignifikánsan gyakoribb volt a jóindulatú gastroduodenalis fekély $(21,4 \%$ vs. $7 \%$, $\mathrm{p}<0,001)$ és a nyelőcső-varicositas $(8,2 \%$ vs. $3,3 \%$, p<0,001), míg a gyomorpolip és a gyomorrák esetében nem találtunk különbséget a vérző és nem vérző betegek között (1. táblázat).

A kolonoszkópiák során 29,9\%-ban fordult elő vastagbélpolip, 22,4\%-ban vastagbél-diverticulosis, 6,9\%-ban colorectalis rák és 9,7\%-ban gyulladásos bélbetegség. Az esetek 28,9\%-ában volt a GI-vérzés a vizsgálat indikációja. A vérzés miatt vizsgált betegek között gyakoribb volt a colorectalis daganat $(13,2 \%$ vs. $4,3 \%, \mathrm{p}<0,001)$ és a gyulladásos bélbetegség ( $12,3 \%$ vs. $8,6 \%, p=0,02)$, de nem volt szignifikáns különbség a polipok és a diverticulosis tekintetében a két csoport között (2. táblázat).

A vérzés indikációjával történt endoszkópiákat tovább bontottuk a vérzés manifeszt vagy okkult jellege alapján (manifeszt/okkult vérzés: gasztroszkópia: 37,9\%/62,1\%, kolonoszkópia: 31,4\%/68,6\%). A manifeszt vérzés indikációjával gasztroszkópiára kerülő betegek körében magasabb volt a peptikus fekélybetegség (32,8\% vs. 9,1\%) és a nyelőcső-varicositas $(10,3 \%$ vs. $5,1 \%)$ aránya. Az alsó endoszkópiák során a colorectalis daganat $(15,0 \%$ vs.

1. táblázat |A felső endoszkópiák során észlelt diagnózisok gyakoriságai

\begin{tabular}{|c|c|c|c|c|c|}
\hline \multirow{2}{*}{ Diagnózisok } & \multirow{2}{*}{$\begin{array}{l}\text { Összes } \\
\text { elvégzett } \\
\text { gasztro- } \\
\text { szkópia } \\
(\mathrm{n}= \\
1789)\end{array}$} & \multicolumn{3}{|c|}{$\begin{array}{l}\text { GI-vérzés indikációjával } \\
\text { végzett gasztroszkópia }\end{array}$} & \multirow{2}{*}{$\begin{array}{l}\text { Egyéb } \\
\text { indiká- } \\
\text { cióval } \\
\text { végzett } \\
\text { gasztro- } \\
\text { szkópia } \\
(\mathrm{n}= \\
1314)\end{array}$} \\
\hline & & $\begin{array}{l}\text { Összes } \\
(\mathrm{n}= \\
475)\end{array}$ & $\begin{array}{l}\text { Mani- } \\
\text { feszt } \\
\text { vérző } \\
(\mathrm{n}= \\
180)\end{array}$ & $\begin{array}{l}\text { Okkult } \\
\text { vérző } \\
(\mathrm{n}= \\
295)\end{array}$ & \\
\hline $\begin{array}{l}\text { Jóindulatú } \\
\text { fekélybetegség }\end{array}$ & $10,8 \%$ & $21,4 \%$ & $32,8 \%$ & $9,1 \%$ & $7,0 \%$ \\
\hline $\begin{array}{l}\text { Nyelöcsö- } \\
\text { varicositas }\end{array}$ & $4,5 \%$ & $8,2 \%$ & $10,3 \%$ & $5,1 \%$ & $3,3 \%$ \\
\hline Gyomorpolip & $6,1 \%$ & $6,2 \%$ & $5,2 \%$ & $5,7 \%$ & $6,0 \%$ \\
\hline Gyomorrák & $2,9 \%$ & $3,8 \%$ & $4,3 \%$ & $3,4 \%$ & $2,5 \%$ \\
\hline
\end{tabular}

2. táblázat $\mid$ Az alsó endoszkópiák során észlelt diagnózisok gyakoriságai

\begin{tabular}{|c|c|c|c|c|c|}
\hline \multirow{3}{*}{ Diagnózisok $\begin{array}{r}\text { Betegcsoportok a } \\
\text { vizsgálat } \\
\text { indikációja } \\
\text { szerint }\end{array}$} & \multirow{3}{*}{$\begin{array}{l}\text { Összes } \\
\text { elvég- } \\
\text { zett } \\
\text { kolono- } \\
\text { szkópia } \\
(\mathrm{n}= \\
1676)\end{array}$} & \multicolumn{3}{|c|}{$\begin{array}{l}\text { GI-vérzés indikációjával } \\
\text { végzett kolonoszkópia }\end{array}$} & \multirow{3}{*}{$\begin{array}{l}\text { Egyéb } \\
\text { indikáci- } \\
\text { óval } \\
\text { végzett } \\
\text { kolono- } \\
\text { szkópia } \\
(\mathrm{n}= \\
1192)\end{array}$} \\
\hline & & $\begin{array}{l}\text { Összes } \\
(\mathrm{n}= \\
484)\end{array}$ & $\begin{array}{l}\text { Mani- } \\
\text { feszt } \\
\text { vérző } \\
(\mathrm{n}= \\
152)\end{array}$ & $\begin{array}{l}\text { Okkult } \\
\text { vérző } \\
(\mathrm{n}= \\
332)\end{array}$ & \\
\hline & & & & & \\
\hline Vastagbélpolip & $29,9 \%$ & $29,4 \%$ & $22,2 \%$ & $27,9 \%$ & $30,2 \%$ \\
\hline $\begin{array}{l}\text { Colondiver- } \\
\text { ticulosis }\end{array}$ & $22,4 \%$ & $24,2 \%$ & $23,5 \%$ & $20,9 \%$ & $21,7 \%$ \\
\hline Vastagbélrák & $6,9 \%$ & $13,2 \%$ & $15,0 \%$ & $5,8 \%$ & $4,3 \%$ \\
\hline $\begin{array}{l}\text { Gyulladásos } \\
\text { bélbetegség }\end{array}$ & $9,7 \%$ & $12,3 \%$ & $14,4 \%$ & $7,3 \%$ & $8,6 \%$ \\
\hline
\end{tabular}


$5,8 \%$ ) és a gyulladásos bélbetegség ( $14,4 \%$ vs. $7,3 \%)$ fordult elő nagyobb gyakorisággal a manifeszt vérzés gyanújával vizsgált betegek körében (1. és 2. táblázat).

\section{A gastrointestinalis vérzés kockázatával kapcsolatot mutató klinikai tényezök}

A GI-vérzés indikáció miatt felső endoszkópián átesett betegek idôsebbek voltak $(\mathrm{p}<0,001)$, míg a kolonoszkópiák esetén nem találtunk különbséget a két betegcsoport átlagéletkora között. A vérzés indikációjával vizsgált betegcsoportban mind a felsô, mind az alsó endoszkópos vizsgálatok esetén magasabb volt a férfi betegek aránya (OR: $0,62, \mathrm{CI}: 0,4 \mathrm{l}-0,80, \mathrm{p}=0,008$, illetve OR: 0,60, CI: 0,49-0,74, p<0,001). A társbetegségek jelenléte $81 \%$ volt a teljes betegcsoportban. A GI-vérzés indikációja miatt endoszkopizált betegekben gyakrabban fordult elő szívelégtelenség (gasztroszkópia: OR: 2,11, CI: 1,64-2,72, p<0,001 és kolonoszkópia: OR: 1,66, CI: $1,22-2,53, p=0,001)$, veseelégtelenség (OR: 1,45 , CI: $1,05-1,98, p=0,014$ és OR: 1,71, CI: $1,16-2,52, p$ $=0,005)$, hematológiai daganat (OR: 1,83, CI: 1,64$2,72, \mathrm{p}=0,013$ és OR: 3,05 , CI: $1,49-6,25, \mathrm{p}=0,002)$, májcirrhosis (OR: 2,25, CI: 1,62-3,12, p<0,001 és OR: $1,71, \mathrm{CI}: 1,02-2,86, \mathrm{p}=0,029)$ és rendszeres alkoholfogyasztás $(\mathrm{p}=0,013)$ (1. és 2 . ábra). A két csoportnál nem észleltünk különbséget az egyéb társbetegségek, valamint a dohányzási státusz tekintetében. A felső endoszkópos vizsgálatok eredménye azt mutatta, hogy a manifeszt vérzés indikációjával vizsgált betegeknél gyakoribb volt a hematológiai betegség (OR: 2,5, CI: 1,117-5,639, $\mathrm{p}=0,026)$, a nem szteroid gyulladáscsökkentő szer (NSAID) szedése (14,2\% vs. $6 \%$, OR: 2,582 , CI: $1,321-$ $5,050, \mathrm{p}=0,006)$, valamint magasabb volt a rendszeres alkoholfogyasztók aránya $(\mathrm{p}=0,001)$ az okkult vérzés indikációjával vizsgált betegekhez képest.

Rizikógyógyszer-szedés tekintetében a betegek aminoszalicilát (ASA), NSAID, egyéb thrombocytaaggregáció-gátló (TAGG), heparinkészítmények, acenocoumarol és szteroid szedését, rizikófokozó hatását vizsgáltuk. A GI-vérzéssel és az egyéb indikációval vizsgált betegek közel azonos arányban szedtek legalább egy készítményt az előbbiek közül (gasztroszkópiák esetén: 52,3\% vs. $47,1 \%, p=0,469$; kolonoszkópiák esetén: $51,7 \%$ vs. $48,0 \%, \mathrm{p}=0,547)$. Külön elemezve az egyes gyógyszerek szedését, a gasztroszkopizált betegek körében a TAGG (OR: 1,64, CI: 1,07-2,51, p = 0,02), az acenocoumarol (OR: 1,83 , CI: 1,26-2,64, p<0,001) és az alacsony molekulasúlyú heparin (LMWH) (OR: 2,59, CI: $1,63-4,12, \mathrm{p}<0,001)$ fogyasztás mutatkozott gyakoribbnak vérzésindikáció esetén, míg kolonoszkópiák során nem találtunk különbséget az egyes gyógyszerek szedésében (3. ábra).

A vérzés indikációjával felső endoszkópián átesett betegek transzfúziós igénye $23 \%$, az alsó endoszkópián átesett betegek esetén $14 \%$ volt.

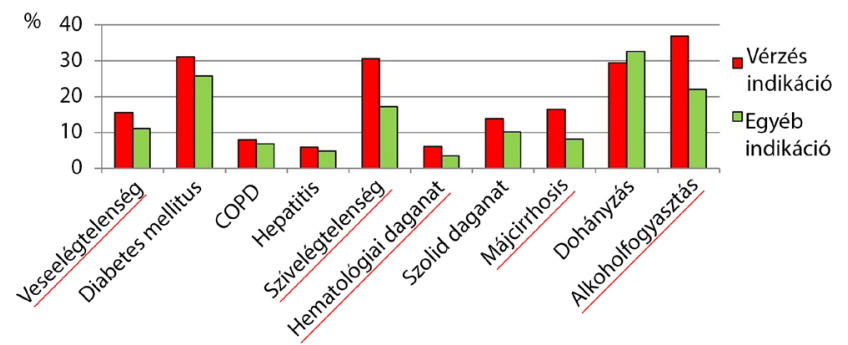

1. ábra Társbetegségek százalékos megoszlása a vérzés és egyéb indikáció miatt felső endoszkópián átesett betegeknél

COPD $=($ chronic obstructive pulmonary disease $)$ krónikus obstruktív tüdőbetegség

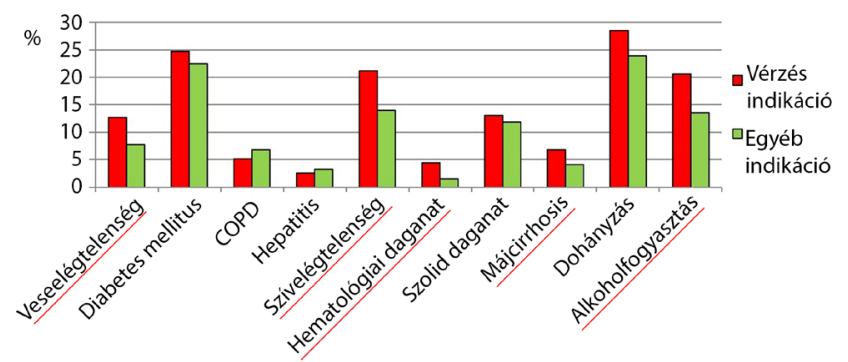

2. ábra $\quad$ Társbetegségek százalékos megoszlása a vérzés és egyéb indikáció miatt alsó endoszkópián átesett betegeknél

COPD $=($ chronic obstructive pulmonary disease $)$ krónikus obstruktív tüdőbetegség

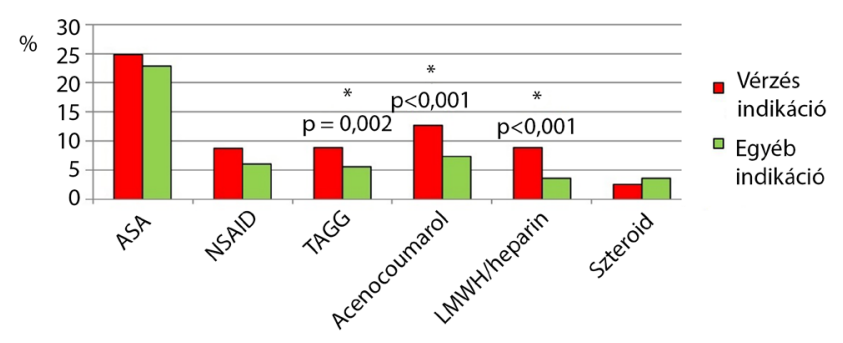

3. ábra

Rizikógyógyszer-szedés százalékos megoszlása a vérzés és egyéb indikáció miatt felső endoszkópián átesett betegeknél

ASA $=($ aminosalicylic acid $)$ aminoszalicilát $\mathrm{LMWH}^{\mathrm{L}}=\left(\mathrm{low} \mathrm{mo}^{-}\right.$ lecular weight heparin) kis molekulatömegű heparin; NSAID = (non-steroidal anti-inflammatory drug) nem szteroid gyulladáscsökkentő gyógyszer; TAGG = thrombocytaaggregáció-gátló

\section{Minőségi mutatók}

A kolonoszkópiák komplettálási aránya 84,6\% volt. A nem vérzés indikációjával vizsgált betegek esetén $87,3 \%$, míg a vérzés indikációjával vizsgáltak között csak 78,0\%-ban sikerült komplett kolonoszkópiát végezni. Az inkomplett kolonoszkópiák hátterében az alábbi tényezők álltak: elégtelen előkészítés $(38,1 \%)$, térszúkítő folyamat $(20,3 \%)$, technikai nehézség $(25,1 \%)$, nem volt cél a komplett kolonoszkópia (16,5\%, például ismert colitis ulcerosa). 
$\mathrm{Az}$ adenomadetekciós ráta $(\mathrm{ADR})$ vizsgált betegeinknél 29,9\% volt (ADR férfi: 31,9\%, illetve ADR nő: $23,3 \%$ ), míg a colorectalis rák detekciós ráta 6,9\%-nak adódott. Szövődményt összesen 12 esetben észleltünk a vizsgált időszakban, 11 esetben vérzést $(0,7 \%)$, illetve egy esetben történt perforáció $(0,1 \%)$.

\section{Megbeszélés}

A vizsgált időszak alatt elvégzett felső és alsó endoszkópos vizsgálatok során talált diagnózisok gyakorisági adatai jól korrelálnak a nemzetközi irodalomban közölt adatokkal [2-5, 8-10, 22-29]. Vizsgált betegpopulációnkra a magas átlagéletkor (61 év) és magas komorbiditási arány jellemező, a betegek mintegy $81 \%$-a rendelkezett társbetegséggel. Mindez összhangban van a rizikógyógyszer-szedés igen magas arányával.

A felső endoszkópos vizsgálatok esetén a peptikus fekélybetegség 10,8\%-os előfordulása magasabb egyes olasz, kanadai és finn centrumból származó hasonló vizsgálat adatainál $(2,8 \%, 5,3 \%$, illetve $7 \%)$, azonban alacsonyabb egy dán vizsgálat eredményeinél (15,7\%) [28, 30-32]. A gyomorrák előfordulása magasabb, mint az előbb említett tanulmányok adatai ( $0,3 \%$ és $0,7 \%)$, azonban e vizsgálatok beteganyagából a súlyos komorbid betegek kizárásra kerültek $[28,32]$. Egy 65 évesnél idősebb betegpopuláció endoszkópos elváltozásait feldolgozó olasz tanulmányban a peptikus fekélybetegség, malignitás és a gyomorpolip elófordulása ugyanakkor megfelelt jelen vizsgálatunk adatainak $(7,2 \%, 2,9 \%, 4,1 \%)$ [33]. Nyelőcső-varicositas az általunk vizsgált cirrhoticus betegek 44\%-ában került felismerésre, ami összhangban van az irodalmi adatokkal [34]. Enyhe erozív gastritisek arányára és osztályozására nem tértünk ki, ezekből ugyanis szövettani mintavétel sem történt.

Az elvégzett kolonoszkópiák során a vastagbélpolipok detektálási rátája 29,9\% volt. Hasonló adenomatalálati arányokat közöltek más, a kolonoszkópiák minőségi indikátorait, diagnosztikus teljesítményét vizsgáló kanadai és egyesült államokbeli tanulmányok is $(34 \%$, illetve $23 \%$ ) $[35,36]$. A 2012-es európai ajánlások (ESGE), illetve a U.S. Multi-Society Task Force on Colorectal Cancer ajánlása alapján az 50 év feletti betegpopulációban férfiakban minimum $25 \%$, nők esetén minimum $15 \%$ adenomadetektálási ráta az elvárható [21, 37]. Saját centrumunk adatai ezen elvárásoknak megfelelnek (ADR férfi: $31,9 \%$, illetve ADR nő: $23,3 \%)$.

Colorectalis rák tekintetében az irodalmi adatok nagy szórást mutatnak. Az 50 év feletti aszimptómás betegcsoportokban végzett screening kolonoszkópiák kevesebb mint 1\%-ában fordul elő vastagbélrák [38, 39]. Jelentősen magasabb gyakoriságokat $(3,3 \%-7,1 \%)$ közölnek olyan tanulmányok, amelyekben szimptómás, fennjáró, illetve kórházi bennfekvő betegek egyaránt szerepelnek [35, 40, 41]. Az általunk megfigyelt 6,9\%-os előfordulási gyakoriság igen magasnak tekinthető, azonban megfelel más, hasonlóan idős, polimorbid betegeket nem kizáró betegpopulációjú vizsgálatok adatainak [40, 41]. A diverticulosis prevalenciája 40 éves kor alatt 5\%, 60 év feletti korcsoportban azonban már meghaladja a $30 \%$-ot $[42,43]$. Vizsgálatunkban 22,4\%-ban fordult elő diverticulosis. A gyulladásos bélbetegségek emelkedett gyakorisággal szerepelnek diagnózisaink között, ez azonban a klinika speciális érdeklődésével, IBD-centrum státuszával magyarázható.

A GI-vérzés indikációjával végzett felső endoszkópiák során diagnosztizált laesiók gyakoriságai megfelelnek az irodalmi adatoknak $[2,22,44-46]$. A manifeszt vérzés gyanúja miatt endoszkopizált betegekben 32,8\%-ban találtunk peptikus fekélybetegséget, hasonlóan egyes, akut felső GI-vérzést vizsgáló skót, angol és francia centrumok által közölt találati arányokhoz [2, 45, 46]. Egy olasz tanulmány ennél is magasabb gyakoriságokat $(47,6 \%)$ közöl a manifeszt vérző betegek esetén [10]. Az American Gastroenterological Association (AGA) 2000ben megjelent összefoglaló cikke alapján az okkult vérző betegek körében a gasztroszkópos vizsgálat 4-11\%-ban tár fel peptikus fekélyt [44]. A gastrooesophagealis varixok gyakorisága a manifeszt vérző betegek körében szintén jól korrelál a már említett tanulmányokkal $[2,10$, $45,46]$. A gyomorcarcinomák és jóindulatú gyomorpolipok előfordulása nem különbözik számottevően a vérző és nem vérző betegpopulációk között, gyakoriságaik az előzőekben már említett irodalmi adatokhoz hasonlóak [33]. A peptikus fekélybetegség és a gastrooesophagealis varixok magasabb előfordulása a vérzéses indikációval endoszkopizált betegek körében, azon belül is a manifeszt vérzéssel jelentkező betegek esetén, nem meglepő módon igazolja ezen laesiók jelentős vérzékenységi hajlamát, illetve elsődleges kóroki jelentőségüket az akut felső GI-vérzésekben [22, 34].

A kolonoszkópos vizsgálatokat szintén tovább osztályoztuk GI-vérzés és egyéb indikációval végzett vizsgálatokra. A leggyakoribb diagnózisok a vastagbélpolip és a vastagbél-diverticulosis voltak. Ezen laesiók találati arányában nem volt különbség a vérző és nem vérző betegpopuláció között, és a gyakoriságok megfelelnek a korábban említett irodalmi adatoknak $[35,36,42,43]$. Bár a diverticulumokból eredő vérzés az akut alsó GI-vérzések leggyakoribb oka (24-47\%), a diverticulumok csak igen csekély hányadából származik vérzés [47, 48]. A colorectalis daganatok találati arányában már szignifikáns különbség adódott vérző és nem vérző betegcsoportok között (13,2\% vs. 4,3\%). Rex és mtsai összefoglaló cikkükben a vérzéses indikációval (haematochesia és okkult vérzés egyaránt) végzett kolonoszkópiák colorectalis rákra vonatkozó találati arányait hasonlónak találták (7,7-11,2\%) [49]. A manifeszt és okkult vérzés indikációjával vizsgált betegekben megfigyelt találati gyakoriságok $(15,0 \%$, illetve $5,8 \%)$ szintén korrelálnak a hasonló betegpopulációkat vizsgáló tanulmányokkal [47, 50]. Egy amerikai vizsgálat 60-69 éves, okkult vérző (pozitív széklet okkult vér teszt) betegcsoport endoszkópos vizsgálata során 7,1\%-ra becsülte a colorectalis rák előfordu- 
lását [50]. A vastagbéldaganat magasabb előfordulása a vérzés indikációjával endoszkópos vizsgálatra kerülő betegekben és szintén magas aránya a manifeszt vérzés gyanúját felvető esetekben tükrözi, hogy ezen elváltozások igen jelentős hányadukban ( $60 \%)$ járnak emésztőszervi vérzéssel, és ezen belül is jelentős a manifeszt vérző betegek száma [51, 52].

Amint az korábban is említésre került, jelen betegpopulációnkban a társbetegségek jelenléte és a rizikógyógyszer szedése igen gyakori. GI-vérzés indikációjával endoszkópiára kerülő betegeink körében az ASA-fogyasztás $(24,8 \%)$ aránya hasonlónak mutatkozik más olasz és portugál tanulmányok adataihoz $(24,2 \%$ és $28,0 \%)$, az NSAID szerek fogyasztását azonban jóval alacsonyabbnak becsültük $(8,7 \%)$ az előbb említett tanulmányoknál $(18,1-22,0 \%)[10,22,23,53]$. Magasabbnak mutatkozott a vérzés indikációjával gasztroszkópián átesett betegeinkben az acenocoumarol-, LMWH- és az egyéb TAGG-fogyasztás. Megjegyzendő, hogy az egyéb TAGG-gyógyszert fogyasztó betegek 37\%-a kettős thrombocytagátló kezelésben részesült.

Betegpopulációnkban a társbetegségek jelenléte $81 \%$ volt. Több tanulmány is közel 40\%-ra becsüli az akut felső GI-vérzéssel jelentkező betegeknél a súlyos társbetegségek jelenlétét, amely az idős, bennfekvő betegek körében $75 \%$-ot is elérhet, jelentősen emelve a populáció mortalitását $[8,10]$. Idős, polimorbid betegeink körében a szívelégtelenség, a hematológiai daganat, veseelégtelenség, illetve a májcirrhosis jelentett fokozott rizikót a GI-vérzésre $[7,8,54]$.

Jelen tanulmányunkban a kolonoszkópiák minőségi indikátorai közül az adenomadetekciós rátára, illetve a kolonoszkópiák komplettálási rátájára vonatkozóan rendelkezünk adatokkal. Az adenomadetekciós ráta nemzetközi ajánlások szerinti elvárható minimumait korábban már említettük, és a vizsgált időszakban elvégzett kolonoszkópos vizsgálataink ezen minimumértékeknek megfeleltek [21, 37]. A vizsgálatok elvárható komplettálási rátájára vonatkozóan nincs teljes konszenzus a különböző ajánlások között. Európai guideline-ok 90\%ban határozzák meg a coecumintubációs ráta minimumát, míg kanadai ajánlások 95\%-ot kívánnak meg $[55,56]$. Az amerikai ajánlás megkülönböztet „screening” és „szimptomatikus” betegpopulációkat, ami alapján 95\%, illetve 90\%-ban írja elő az elvárható coecumintubációs rátát [21]. Saját eredményeinkben a komplettálási arány $84,6 \%$ volt, amely összehasonlítva egy egyesült államokbeli és kanadai tanulmánnyal, elmarad azok 96,3\% és 92\%-os komplettálási rátáitól [35, 36]. Megjegyzendő azonban, hogy saját eredményünk tartalmazza a vizsgálatok biztos diagnózis vagy endoszkópos beavatkozás miatti szándékos leállítását is, továbbá az említett amerikai centrumból származó adat olyan betegpopulációból származik, amely screening kolonoszkópián vett részt, és a szimptómás betegek (GI-vérzés, anaemia, anamneszti- kus rák/polip) kizárásra kerültek. Kolonoszkópiáink komplettálási rátája 87,3\%-ra ugrik, ha nem vesszük számításba a daganatos szúkületek miatti inkomplett vizsgálatokat, illetve eléri a 96,8\%-ot, ha az elégtelen előkészítés miatt meghiúsult vizsgálatokat is kizárjuk. A nem megfelelő bélelőkészítés más tanulmányok alapján is az inkomplett vizsgálatok leggyakoribb okaként szerepel, és jelentősen rontja a vizsgálat diagnosztikus teljesítményét, szignifikánsan alacsonyabb adenomadetekciós ráták figyelhetők meg a nem megfelelően előkészített betegcsoportokban $[35,57]$. Ennélfogva kolonoszkópos vizsgálataink komplettálási rátáján elsősorban a megfelelő előkészítés biztosításával javíthatunk.

Vizsgálatunk értékét korlátozza, hogy egy klinikai centrum adatait tükrözi, ezért nem tekinthető reprezentatívnak az áltagpopulációra nézve. További limitáció lehet az adatok elemzésének retrospektív jellege. Erősségnek tekinthető azonban a széles körü adatgyüjtés, beleértve a társbetegségeket, gyógyszeres kezelést, dohányzást, alkoholfogyasztást és a transzfúziós igényt.

\section{Következtetés}

Elmondható, hogy az általunk talált endoszkópos diagnózisok megfelelnek a nemzetközi ajánlásoknak, illetve korrelálnak azokkal a szakirodalmi adatokkal, amelyekben hasonló korú és komorbiditási aránnyal rendelkező betegcsoportot vizsgáltak. Ugyanakkor a kolonoszkópiakomplettálási arányunk elmarad az elvárt értéktől, amelyen az előkészítés pontosabb betartatásával, a betegtájékoztatás fejlesztésével javíthatunk a jövőben.

Anyagi támogatás: A kutatás az OTKA (Országos Tudományos Kutatási Alapprogramok) támogatásában részesült. Grant ID: $115345 ; 2015$.

Szerzôi munkamegosztás: G. L.: Adatgyüjtés, irodalomkutatás, a kézirat megírása. K. Zs.: Adatgyüjtés, a kézirat megírása. G. P., V. Zs., L. B.: Adatgyújtés, a kézirat javítása. D. A., S. A., S. L., M. O.: Adatgyújtés. K. L., P. J., G. K.: Endoszkópia, a kézirat javítása. L. P. L.: Vizsgálatvezető, adatgyújtés, irodalomkutatás, a kézirat javítása, endoszkópia. A cikk végleges változatát valamennyi szerző elolvasta és jóváhagyta.

Érdekeltségek: A szerzőknek nincsenek érdekeltségeik.

\section{Köszönetnyilvánítás}

Köszönjük Dr. Mohás Annának, Dr. Mórocza-Szabó Ágnesnek, Dr. Csákó Bencének és Dr. Szilágyi Blankának az adatgyújtésben nyújtott segítséget. Kecse Éva és Gáspár Szilvia endoszkópos asszisztenseknek köszönjük, hogy a vizsgálatok végzésénél segítették munkánkat. 


\section{Irodalom}

[1] ASGE Standards of Practice Committee, Early, D. S., Ben-Mena chem, T., Decker, G. A., et al.: Appropriate use of GI endoscopy. Gastrointest. Endosc., 2012, 75(6), 1127-1131.

[2] Blatchford, O., Davidson, L. A., Murray, W. R., et al.: Acute up per gastrointestinal haemorrhage in west of Scotland: case ascertainment study. BMJ, 1997, 315(7107), 510-514.

[3] Yavorski, R. T., Wong, R. K., Maydonovitch, C., et al.: Analysis of 3,294 cases of upper gastrointestinal bleeding in military medical facilities. Am. J. Gastroenterol., 1995, 90(4), 568-573.

[4] Longstreth, G. F.: Epidemiology and outcome of patients hospitalized with acute lower gastrointestinal hemorrhage: a population-based study. Am. J. Gastroenterol., 1997, 92(3), 419-424.

[5] Hreinsson, J. P., Gumundsson, S., Kalaitzakis, E., et al.: Lower gastrointestinal bleeding: incidence, etiology, and outcomes in a population-based setting. Eur. J. Gastroenterol. Hepatol., 2013, 25(1), 37-43.

[6] Esrailian, E., Gralnek, I. M.: Nonvariceal upper gastrointestinal bleeding: epidemiology and diagnosis. Gastroenterol. Clin. North Am., 2005, 34(4), 589-605.

[7] Strate, L. L.: Lower GI bleeding: epidemiology and diagnosis Gastroenterol. Clin. North Am., 2005, 34(4), 643-664.

[8] Lanas, A., García-Rodríguez, L. A., Polo-Tomás, M., et al.: Time trends and impact of upper and lower gastrointestinal bleeding and perforation in clinical practice. Am. J. Gastroenterol., 2009, 104(7), 1633-1641

[9] Van Leerdam, M. E., Vreeburg, E. M., Rauws, E. A., et al.: Acute upper GI bleeding: did anything change? Time trend analysis of incidence and outcome of acute upper GI bleeding between 1993/1994 and 2000. Am. J. Gastroenterol., 2003, 98(7), 1494-1499.

[10] Loperfido, S., Baldo, V., Piovesana, E., et al.: Changing trends in acute upper-GI bleeding: a population-based study. Gastrointest. Endosc., 2009, 70(2), 212-224.

[11] Rácz, I., Kárász, T., Lukács, K., et al.: Management of peptic ulcer bleeding in different case volume workplaces: results of a nationwide inquiry in Hungary. Gastroenterol. Res. Pract., 2012, 2012, Article ID 956434

[12] Szôcs, K., Kárász, T., Saleh, H., et al.: The value of routine sec ond-look endoscopy in the management of the acute gastroduodenal ulcer bleeding. [A tervezett ellenőrző endoszkópia értéke az akut gastroduodenalis fekélyvérzés ellátásában.] Orv. Hetil. 2009, 150(42), 1932-1936. [Hungarian]

[13] Dávid, G., Mester, G., Pandúr, T., et al.: Management strategies of acute lower gastrointestinal bleeding (ALGIB) of our department. Results of the last two years (2004-2005). Z. Gastroenterol., 2006, 44(5), A19.

[14] Peery, A. F., Dellon, E. S., Lund, J., et al.: Burden of gastrointestinal disease in the United States: 2012 update. Gastroenterology, 2012, 143(5), 1179-1187.e3

[15] Wanders, L. K., van Doorn, S. C., Fockens, P., et al.: Quality of colonoscopy and advances in detection of colorectal lesions: a current overview. Expert Rev. Gastroenterol. Hepatol., 2015, 9(4), 417-430

[16] ASGE Standards of Practice Committee, Pasha, S. F., Shergill, A., Acosta, R. D., et al.: The role of endoscopy in the patient with lower GI bleeding. Gastrointest. Endosc., 2014, 79(6), 875885

[17] Bressler, B., Paszat, L. F., Chen, Z., et al.: Rates of new or missed colorectal cancers after colonoscopy and their risk factors: a population-based analysis. Gastroenterology, 2007, 132(1), 96-102.

[18] Hosokawa, O., Shirasaki, S., Kaizaki, Y., et al.: Invasive colorectal cancer detected up to 3 years after a colonoscopy negative for cancer. Endoscopy, 2003, 35(6), 506-510.

[19] Farrar, W. D., Sawhney, M. S., Nelson, D. B., et al.: Colorectal cancers found after a complete colonoscopy. Clin. Gastroenterol. Hepatol., 2006, 4(10), 1259-1264.
[20] Gellad, Z. F., Voils, C. I., Lin, L. et al.: Physician perceptions on colonoscopy quality: results of a National Survey of Gastroenterologists. Gastroenterol. Res. Pract., 2014, 2014, Article ID 510494.

[21] Rex, D. K., Bond, J. H., Winawer, S., et al.: Quality in the technical performance of colonoscopy and the continuous quality improvement process for colonoscopy: recommendations of the U.S. Multi-Society Task Force on Colorectal Cancer. Am. J. Gastroenterol., 2002, 97(6), 1296-1308.

[22] Van Leerdam, M. E.: Epidemiology of acute upper gastrointestinal bleeding. Best Pract. Res. Clin. Gastroenterol., 2008, 22(2), 209-224.

[23] Fonseca, J., Alves, C. C., Neto, R., et al.: Nonvariceal upper gastrointestinal bleeding in Portugal: A multicentric retrospective study in twelve Portuguese hospitals. Gastroenterol. Hepatol., 2012, 35(6), 377-385.

[24] Lanas, A., Aabakken, L., Fonseca, J., et al.: Variability in the management of nonvariceal upper gastrointestinal bleeding in Europe: an observational study. Adv. Ther., 2012, 29(12), 10261036.

[25] Kim, J. J., Sheibani, S., Park, S., et al.: Causes of bleeding and outcomes in patients hospitalized with upper gastrointestinal bleeding. J. Clin. Gastroenterol., 2014, 48(2), 113-118.

[26] Zuccaro, G.: Epidemiology of lower gastrointestinal bleeding. Best Prac. Res. Clin. Gastroenterol., 2008, 22(2), 225-232.

[27] Strate, L. L., Ayanian, J. Z., Kotler, G., et. al.: Risk factors for mortality in lower intestinal bleeding. Clin. Gastroenterol. Hepatol., 2008, 6(9), 1004-1010.

[28] Zullo, A., Esposito, G., Ridola, L., et al.: Prevalence of lesions detected at upper endoscopy: An Italian survey. Eur. J. Intern. Med., 2014, 25(8), 772-776.

[29] Park, W. G., Shaheen, N. J., Cohen, J., et al.: Quality indicators for EGD. Gastrointestinal Endoscopy, 2015, 81(1), 17-30.

[30] Voutilainen, M., Mäntynen, T., Färkkilä, M., et al.: Impact of nonsteroidal anti-inflammatory drug and aspirin use on the prevalence of dyspepsia and uncomplicated peptic ulcer disease. Scand. J. Gastroenterol., 2001, 36(8), 817-821.

[31] Lassen, A., Hallas, J., De Muckadell, O. B., et al.: First-time endoscopy and use of antisecretory medication: a population-based cohort study. Scand. J. Gastroenterol., 2005, 40(6), 705-712.

[32] Thomson, A. B., Barkun, A. N., Armstrong, D., et al.: The prevalence of clinically significant endoscopic findings in primary care patients with uninvestigated dyspepsia: the Canadian Adult Dyspepsia Empiric Treatment - Prompt Endoscopy (CADET-PE) study. Aliment. Pharmacol. Ther., 2003, 17(12), 1481-1491.

[33] Buri, L., Zullo, A., Hassan, C., et al.: Upper GI endoscopy in elderly patients: predictive factors of relevant endoscopic findings. Intern. Emerg. Med., 2013, 8(2), 141-146.

[34] Triantos, C., Kalafateli, M., et al.: Endoscopic treatment of esophageal varices in patients with liver cirrhosis. World J. Gastroenterol., 2014, 20(36), 13015-13026.

[35] Singh, H., Kaita, L., Taylor, G., et al.: Practice and documentation of performance of colonoscopy in a central Canadian health region. Can. J. Gastroenterol. Hepatol., 2014, 28(4), 185-190.

[36] Rai, T., Navaneethan, U., Gohel, T., et al.: Effect of quality of bowel preparation on quality indicators of adenoma detection rates and colonoscopy completion rates. Gastroenterol. Rep. (Oxf.), 2016, 4(2), 148-153.

[37] Rembacken, B., Hassan, C., Riemann, J. F., et al.: Quality in screening colonoscopy: position statement of the European Society of Gastrointestinal Endoscopy (ESGE). Endoscopy, 2012, 44(10), 957-968.

[38] Altenhofen, L., Kretschmann, J., et al.: Trends in adenoma detec tion rates during the first 10 years of the German Screening Colonoscopy Program. Gastroenterology, 2015, 149(2), 356-366.

[39] Lieberman, D. A., Weiss, D. G., Bond, J. H., et al.: Use of colonoscopy to screen asymptomatic adults for colorectal cancer. Veter- 
ans Affairs Cooperative Study Group 380. N. Engl. J. Med., 2000, 343(3), 162-168.

[40] Ure, T., Dehghan, K., Vernava, A. M. 3rd, et al.: Colonoscopy in the elderly. Low risk, high yield. Surg. Endosc., 1995, 9(5), 505508.

[41] Karajeh, M. A., Sanders, D. S., Hurlstone, D. P., et al.: Colonoscopy in elderly people is a safe procedure with a high diagnostic yield: a prospective comparative study of 2000 patients. Endoscopy, 2006, 38(3), 226-230.

[42] Manousos, O. N., Truelove, S. C., Lumsden, K., et al.: Prevalence of colonic diverticulosis in general population of Oxford area. Br. Med. J., 1967, 3(5568), 762-763.

[43] Gohil, V. B., Patrie, J. T., Shami, V. M., et al.: Colonic diverticulosis is associated with an increased adenoma detection rate in patients undergoing first-time screening colonoscopy. J. Interv. Gastroenterol., 2012, 2(2), 70-75.

[44] Zuckerman, G. R., Prakash, C., Askin, M. P., et al.: AGA technical review on the evaluation and management of occult and obscure gastrointestinal bleeding. Gastroenterology, 2000, 118(1), 201221 .

[45] Rockall, T. A., Logan, R. F., Devlin, H. B., et al.: Incidence of and mortality from acute upper gastrointestinal haemorrhage in the United Kingdom. Steering committee and members of the $\mathrm{Na}$ tional Audit of Acute Upper Gastrointestinal Haemorrhage. BMJ, 1995, 311(6999) 222-226.

[46] Czernichow, P., Hochain, P., Nousbaum, J. B., et al.: Epidemiology and course of acute upper gastro-intestinal haemorrhage in four French geographical areas. Eur. J. Gastroenterol. Hepatol., 2000, 12(2), 175-181.

[47] Lingenfelser, T., Ell, C.: Lower intestinal bleeding. Best Pract. Res. Clin. Gastroenterol., 2001, 15(1), 135-153.

[48] Niikura, R., Nagata, N., Shimbo, T., et al.: Natural history of bleeding risk in colonic diverticulosis patients: a long-term colonoscopy-based cohort study. Aliment. Pharmacol. Ther., 2015, $41(9), 888-894$.
[49] Rex, D. K.: Colonoscopy: a review of its yield for cancers and adenomas by indication. Am. J. Gastroenterol., 1995, 90(3), 353-365.

[50] Neely, D., Campbell, W., Davey, P., et al.: Colorectal cancer screening: the northern trust experience. Ulster Med. J., 2013, $82(3), 160-163$.

[51] Saidi, H. S., Karuri, D., Nyaim, E. O., et al.: Correlation of clinical data, anatomical site and disease stage in colorectal cancer. East Afr. Med. J., 2008, 85(6), 259-262.

[52] Majumdar, S. R., Fletcher, R. H., Evans, A. T.: How does colorectal cancer present? Symptoms, duration, and clues to location. Am. J. Gastroenterol., 1999, 94(10), 3039-3045.

[53] Wolfe, M. M., Lichtenstein, D. R., Singh, G.: Gastrointestinal toxicity of nonsteroidal antiinflammatory drugs. N. Engl. J. Med., 1999, 340(24), 1888-1899.

[54] Leontiadis, G. I., Molloy-Bland, M., Moayyedi, P., et al.: Effect of comorbidity on mortality in patients with peptic ulcer bleeding: systematic review and meta-analysis. Am. J. Gastroenterol., 2013, 108(3), 331-345.

[55] Quirke, P., Risio, M., Lambert, R., et al.: European guidelines for quality assurance in colorectal cancer screening and diagnosis. First Edition - Quality assurance in pathology in colorectal cancer screening and diagnosis. Endoscopy, 2012, 44(Suppl. 3), SE116-SE130.

[56] Rabeneck, L., Rumble, R. B., Axler, J., et al.: Cancer Care Ontario Colonoscopy Standards: standards and evidentiary base. Can. J. Gastroenterol., 2007, 21(Supl. D), 5D-24D.

[57] Oh, C. H., Lee, C. K., Kim, J. W.: Suboptimal bowel preparation significantly impairs colonoscopic detection of non-polypoid colorectal neoplasms. Dig. Dis. Sci., 2015, 60(8), 2294-2303.

(Lakatos Péter László dr., Budapest, Korányi Sándor u. 2/A, 1083 e-mail: lakatos.peter_laszlo@med.semmelweis-univ.hu)

\section{A rendezvények és kongresszusok híranyagának leadása}

a lap megjelenése előtt legalább 40 nappal lehetséges, a 6 hetes nyomdai átfutás miatt. Kérjük megrendelőink szíves megértését.

A híranyagokat a következő címre kérjük: Orvosi Hetilap titkársága: Budai.Edit@akkrt.hu Akadémiai Kiadó Zrt. 